\title{
Different hormonal requirements of pig oocyte-cumulus complexes during maturation in vitro
}

\author{
H. Funahashi, T. Cantley and B. N. Day* \\ Department of Animal Sciences, University of Missouri-Columbia, Columbia, MO 65211, USA
}

\begin{abstract}
Cytoplasmic maturation as determined by male pronuclear formation following fertilization in vitro was examined in pig oocytes cultured under different hormonal conditions during either the first or second $20 \mathrm{~h}$ period of in vitro maturation. Exposure to several combinations of pregnant mares' serum gonadotrophin (PMSG) (10 iu ml $\mathrm{ml}^{-1}$ ), hCG (10 iu ml ${ }^{-1}$ ) and oestradiol $\left(1 \mu \mathrm{g} \mathrm{ml}^{-1}\right.$ ) for a second $20 \mathrm{~h}$ period following culture in a medium supplemented with these hormones for $20 \mathrm{~h}$ did not result in differences among treatment groups in maturation rates, penetration rates or polyspermy rates. However, supplementation with PMSG and oestradiol for the last $20 \mathrm{~h}$ of culture reduced male pronuclear formation rates significantly. When oocyte-cumulus complexes were cultured in hormone-free media for $20 \mathrm{~h}$ after culture in several combinations of supplemental hormones for the first $20 \mathrm{~h}$ period, germinal vesicle breakdown rates and maturation rates were lower in oocytes previously exposed to oestradiol alone or no hormonal supplements $(68-70 \%$ and $45-49 \%$, respectively) than in oocytes previously exposed to PMSG or hCG $(89-99 \%$ and $71-89 \%$, respectively). Exposure of oocytes to oestradiol alone also reduced the penetration rate $(61 \%)$ compared with PMSG or hCG $(86-99 \%)$. Supplementation of media with PMSG alone or together with other hormones increased the male pronuclear formation rate $(63-72 \%)$ compared with supplementation with oestradiol $(33 \%)$ or no hormonal supplements $(32 \%)$. The concentration of oestradiol in maturation medium decreased at filtration (to $216.5 \pm 72.6 \mathrm{ng} \mathrm{ml}^{-1}$ ) before culture. Under paraffin oil, the concentration further decreased during equilibration (to $128.0 \pm 13.3 \mathrm{ng} \mathrm{ml}^{-1}$ ), during the first $20 \mathrm{~h}$ of culture $\left(42.8 \pm 19.4 \mathrm{ng} \mathrm{ml}^{-1}\right)$ and also during the second $20 \mathrm{~h}$ period of culture without hormonal supplements $\left(0.925 \pm 0.544 \mathrm{ng} \mathrm{ml}^{-1}\right)$. The concentrations of progesterone in maturation media under paraffin oil were lower throughout maturation $\left(1.0 \pm 0.2 \mathrm{ng} \mathrm{ml}^{-1}\right.$ at $\mathrm{Oh}$ to $6.9 \pm 1.5 \mathrm{ng} \mathrm{ml}^{-1}$ after $40 \mathrm{~h}$ ). These results demonstrate that at least two different hormonal conditions during maturation, which are the presence of PMSG during the first $20 \mathrm{~h}$ of culture and the absence of PMSG and oestradiol during the second $20 \mathrm{~h}$ of culture, are beneficial to meiotic and cytoplasmic maturation of pig oocytes. Furthermore, it was demonstrated that oocyte-cumulus complexes under paraffin oil were exposed to extremely low concentrations of steroids during maturation.
\end{abstract}

\section{Introduction}

Addition of suitable hormonal supplementation into maturation media enhances nuclear maturation and cumulus expansion of pig oocyte-cumulus complexes (Meinecke and MeineckeTillmenn, 1979; Hillensjo and Channing, 1980; Minato and Toyoda, 1982; Yoshida et al., 1989; Prochazka et al., 1991). Pig follicular oocyte-cumulus complexes have been cultured in media supplemented with a combination of hormones during maturation in vitro. Recently, we have also indicated that the

*Correspondence.

Received 10 August 1993. removal of hormonal supplements [pregnant mares' serum gonadotrophin (PMSG), hCG and oestradiol] from maturation media after $20 \mathrm{~h}$ of culture enhances cytoplasmic maturation, as determined by male pronuclear formation following fertilization in vitro (Funahashi and Day, 1993c). In control or superovulated pigs, the concentrations of gonadotrophins and steroids in follicular fluid change dramatically during preovulatory oocyte maturation (Moor, 1974; McNatty et al., 1975; Hunter et al., 1976; Ainsworth et al., 1980; Lenton et al., 1988), and, in particular, the concentration of oestrogen in prepubertal gilts declines rapidly between 4 and $16 \mathrm{~h}$ after hCG injection (Ainsworth et al., 1980). There may therefore be different hormonal requirements of oocyte-cumulus complexes for Downloaded from Bioscientifica.com at 04/26/2023 12:40:20PM 
meiotic and cytoplasmic maturation of pig oocytes. The present study was undertaken to examine the ability of pig oocytes to form the male pronucleus following fertilization in vitro when oocyte-cumulus complexes were cultured under the various hormonal conditions during the first and second half of maturation in vifro. Furthermore, we and other investigators have supplemented maturation media maintained under paraffin oil with a high concentration of oestradiol $\left(1 \mu \mathrm{g} \mathrm{ml}^{-1}\right.$; Yoshida et al., 1989, 1990, 1992; Wang et al., 1991; Funahashi and Day, 1993a, b, c). It is known that paraffin oil can absorb lipid-soluble components of culture media (Miller and Pursel, 1987). However, steroid concentrations during maturation are not known. Thus, the concentrations of oestradiol and progesterone in maturation media were determined during culture of pig oocyte-cumulus complexes.

\section{Materials and Methods}

\section{Culture media}

As described by Funahashi and Day (1993c), the basic medium (mM199) was Medium 199 (Earle's salts; Gibco Laboratories, Life Technologies Inc, Grand Island, NY) supplemented with $3.05 \mathrm{mmol}$ D-glucose $1^{-1}, 2.92 \mathrm{mmol}$ calcium lactate $\mathrm{l}^{-1}, 0.91 \mathrm{mmol}$ sodium pyruvate $\mathrm{I}^{-1}, 75 \mu \mathrm{g}$ potassium penicillin $\mathrm{G} \mathrm{ml}^{-1}$ (Sigma Chemical Co., St Louis, MO) and $50 \mu \mathrm{g}$ streptomycin sulfate $\mathrm{ml}^{-1}$. The medium for oocyte maturation was mM199 supplemented with hormones: $10 \mathrm{iu}$ PMSG $\mathrm{ml}^{-1}$ (Intervet America Inc, DE); $10 \mathrm{iu}$ hCG $\mathrm{ml}^{-1}$ (LyphoMed Inc, Rosemont, IL); $1 \mu \mathrm{g}$ oestradiol $\mathrm{ml}^{-1}$ (Sigma Chemical $\mathrm{Co}$ ) and $10 \%(\mathrm{v} / \mathrm{v})$ porcine follicular fluid (PFF). PFF was collected from superficial porcine follicles, $3-6 \mathrm{~mm}$ in diameter. Thereafter, PFF was filtered using 1.20 and $0.45 \mu \mathrm{m}$ syringe filters (Gelman Sciences, Ann Arbor, MI) and stored at $-20^{\circ} \mathrm{C}$ until used. All media used in the present study were filtered using a $0.20 \mu \mathrm{m}$ syringe filter (Schleicher and Schuell, Inc, Keene, NH) immediately before making droplets in culture dishes.

\section{Preparation and culture of oocyte-cumulus complexes}

Ovaries were collected and transported as described previously by Funahashi and Day (1993c). Oocyte-cumulus complexes were aspirated from follicles $3-6 \mathrm{~mm}$ in diameter. Complexes with uniform ooplasm and a compact cumulus cell mass were collected in modified Dulbecco's phosphate-buffered saline (mDPBS) (Funahashi and Day, 1993c) with $2 \%(\mathrm{v} / \mathrm{v})$ newborn piglet serum and then washed three times with mM199 containing 10\% PFF supplemented with hormonal supplements (PMSG, hCG and oestradiol) in Expt 1, or with mM199 supplemented with 10\% PFF only in Expt 2.

In Expt 1 ten oocyte-cumulus complexes were transferred to a droplet of $100 \mu \mathrm{l}$ of mM199 containing $10 \%$ PFF and hormonal supplements covered with warm paraffin oil in a polystyrene culture dish (Becton Dickinson Labware, Oxnard, (A), which had been equilibrated in a $\mathrm{CO}_{2}$ incubator at $39^{\circ} \mathrm{C}$ for $3 \mathrm{~h}$, and then cultured at $39^{\circ} \mathrm{C}$ in an atmosphere of $5 \% \mathrm{CO}_{2}$ in air. After $20 \mathrm{~h}$ of culture, the oocyte-cumulus complexes were removed from the medium and cultured in an equilibrated droplet of $100 \mu \mathrm{l}$ of mM199 containing 10\% PFF supplemented (1) with PMSG, hCG and oestradiol, (2) with PMSG and hCG, (3) with PMSG and oestradiol, (4) with hCG and oestradiol, (5) with PMSG, (6) with hCG, (7) with oestradiol, or (8) with no hormonal supplements for an additional $20 \mathrm{~h}$ period after washing oocyte-cumulus complexes three times in each new medium. All media were covered with paraffin oil and equilibrated in a $\mathrm{CO}_{2}$ incubator at $39^{\circ} \mathrm{C}$ for $3 \mathrm{~h}$ before the start of culture.

In Expt 2, ten oocyte-cumulus complexes were cultured in $100 \mu \mathrm{l}$ of media supplemented with various combinations of hormones as described above for the first $20 \mathrm{~h}$ period of culture for maturation. Thereafter, the oocyte--cumulus complexes were cultured in mM199 containing 10\% PFF for a further $20 \mathrm{~h}$ period following washing three times in the fresh medium. All media were covered with paraffin oil and equilibrated in a $\mathrm{CO}_{2}$ incubator at $39^{\circ} \mathrm{C}$ for $3 \mathrm{~h}$.

\section{Analysis of oestradiol and progesterone in culture media}

To determine the concentration of oestradiol and progesterone in culture media during maturation, 10 and 50 pig oocytecumulus complexes were cultured in a droplet of $100 \mu \mathrm{l}$ and $500 \mu \mathrm{l}$, respectively, of mM199 containing 10\% PFF supplemented with PMSG, hCG and oestradiol under the presence or absence of $5 \mathrm{ml}$ paraffin oil, respectively, for $20 \mathrm{~h}$ at $39^{\circ} \mathrm{C}$ in an atmosphere of $5 \% \mathrm{CO}_{2}$ in air. At the end of culture, oocytecumulus complexes were transferred into $100 \mu \mathrm{l}$ and $500 \mu \mathrm{l}$, respectively, of fresh mM199 containing 10\% PFF supplemented with PMSG, hCG and oestradiol or no hormonal supplements and cultured for $20 \mathrm{~h}$, under the presence or absence of $5 \mathrm{ml}$ of paraffin oil, respectively. All culture media were equilibrated in a $\mathrm{CO}_{2}$ incubator at $39^{\circ} \mathrm{C}$ for $3 \mathrm{~h}$ before the start of culture.

After $0 \mathrm{~h}, 20 \mathrm{~h}$ and $40 \mathrm{~h}$ of maturation culture, conditioned media were collected into $1.5 \mathrm{ml}$ centrifuge tubes. Control samples were also collected before equilibration $(-3 \mathrm{~h}$ of culture). All samples were stored in the freezer at $-20^{\circ} \mathrm{C}$ until radioimmunological analysis. A radioimmunoassay described by Kesler et al. (1977) and validated for pigs by Redmer and Day (1981) was used to determine concentrations of oestradiol in media before and after culturing oocytes-cumulus complexes. Interassay and intra-assay coefficients of variation were $15.5 \%$ and $9.6 \%$, respectively. Assay sensitivity was $4.1 \mathrm{pg} \mathrm{ml} \mathrm{m}^{-1}$. Progesterone concentrations in conditioned media were measured by radioimmunoassay procedures described by Flowers et al. (1989). Mean interassay and intra-assay coefficients of variation were $10.9 \%$ and $7.7 \%$, respectively. Assay sensitivity was $0.2 \mathrm{ng} \mathrm{ml}^{-1}$.

\section{Sperm preparation and in vitro fertilization}

Sperm-rich fractions $(15 \mathrm{ml})$ were collected from a boar, kept at $20^{\circ} \mathrm{C}$ for $16 \mathrm{~h}$ and washed as described by Funahashi and Day (1993c). At the end of washing, the spermatozoa were resuspended at $2 \times 10^{8}$ cells $\mathrm{ml}^{-1}$ in mM199 at $\mathrm{pH} 7.8$ and supplemented with $0.4 \%$ BSA. The sperm suspension was incubated for $90 \mathrm{~min}$ at $37^{\circ} \mathrm{C}$ in an atmosphere of $5 \% \mathrm{CO}_{2}$ in air. 
Table 1. Effects of hormonal supplements between 20 and $40 \mathrm{~h}$ of in vitro maturation on sperm penetration and male pronuclear formation in pigs $12 \mathrm{~h}$ after insemination

\begin{tabular}{|c|c|c|c|c|c|}
\hline \multirow[b]{2}{*}{ Hormonal supplements ${ }^{a}$} & \multicolumn{3}{|c|}{ Number of oocytes } & \multirow{2}{*}{$\begin{array}{c}\text { Number (\%) of } \\
\text { polyspermic oocytes }\end{array}$} & \multirow{2}{*}{$\begin{array}{l}\text { Number }(\%) \text { of } \\
\text { oocytes with male and } \\
\text { female pronuclei }\end{array}$} \\
\hline & Examined & Matured (\%) & Penetrated $(\%)^{b}$ & & \\
\hline PMSG + hCG + oestradiol & 93 & $83(89)$ & $69(83)$ & $45(65)$ & $12(17)^{*}$ \\
\hline PMSG + hCG & 108 & $100(93)$ & $81(81)$ & $57(70)$ & $36(44)^{t, t}$ \\
\hline PMSG + oestradiol & 99 & $89(90)$ & $71(80)$ & $47(66)$ & $18(25)^{*}$ \\
\hline hCG + oestradiol & 88 & $78(89)$ & $57(73)$ & $33(58)$ & $15(26)^{*}$ \\
\hline PMSG & 96 & $90(94)$ & $83(92)$ & $67(81)$ & $28(34)^{* \dagger \dagger}$ \\
\hline hCG & 90 & $82(91)$ & $69(84)$ & $45(65)$ & $36(52)^{\ddagger}$ \\
\hline Oestradiol & 106 & $93(88)$ & $67(72)$ & $44(66)$ & $11(16)^{*}$ \\
\hline None & 73 & $67(92)$ & $47(70)$ & $33(70)$ & $30(64)^{\ddagger}$ \\
\hline
\end{tabular}

aPMSG: 10 iu pregnant mares' serum gonadotrophin $\mathrm{ml}^{-1}$; hCG: 10 iu human chorionic gonadotrophin $\mathrm{ml}^{-1}$; oestradiol: $1 \mu \mathrm{g}$ oestradiol ml ${ }^{-1}$.

bPercentage of oocytes matured.

cPercentage of oocytes penetrated.

${ }^{d}$ Different superscripts within columns denote significant differences $(P<0.05)$.

After $40 \mathrm{~h}$ of culture for maturation, oocytes were used for fertilization in vitro. After removing cumulus cells with mDPBS supplemented with $0.1 \%(\mathrm{w} / \mathrm{v})$ hyaluronidase (Sigma Chemical Co), ten oocytes were washed three times with $50 \mu \mathrm{l}$ of mM199 at $\mathrm{pH} 7.4$ supplemented with $10 \mathrm{mmol}$ caffeine sodium benzoate $\mathrm{l}^{-1}$ and $4 \mathrm{mg} \mathrm{BSA} \mathrm{ml}{ }^{-1}$, and then placed into a droplet of $50 \mu \mathrm{lmM199}$ under paraffin oil, which had been pre-equilibrated in a $\mathrm{CO}_{2}$ incubator at $39^{\circ} \mathrm{C}$ for $3 \mathrm{~h}$. The sperm concentration in preincubated medium $\left(2 \times 10^{8}\right.$ cells ml $\left.{ }^{-1}\right)$

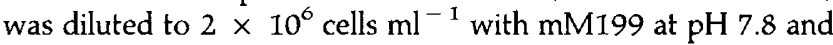
supplemented with $0.4 \%$ BSA (final sperm concentration of $1 \times 10^{6}$ cells $\left.\mathrm{ml}^{-1}\right)$, and $50 \mu \mathrm{l}$ of preincubated spermatozoa was added to $50 \mu \mathrm{l}$ of medium containing oocytes. Oocytes were cultured with spermatozoa for $6 \mathrm{~h}$ at $39^{\circ} \mathrm{C}$ in an atmosphere of $5 \% \mathrm{CO}_{2}$ in air. The eggs were then transferred to $\mathrm{I} \mathrm{ml}$ of fresh Whitten's medium supplemented with $1.5 \%$ BSA (Beckmann and Day, 1993) and cultured at $39^{\circ} \mathrm{C}$ in an atmosphere of $5 \% \mathrm{CO}_{2}$ in air for $6 \mathrm{~h}$ ( $12 \mathrm{~h}$ after insemination) or $12 \mathrm{~h}$ periods ( $18 \mathrm{~h}$ after insemination) in Expt 1 and for a $6 \mathrm{~h}$ period ( $12 \mathrm{~h}$ after insemination) in Expt 2.

\section{Assessment of cytoplasmic maturation}

At the end of culture, eggs were removed from the droplet and washed in $4 \mathrm{ml}$ of mDPBS to remove supernumerary spermatozoa from the zona pellucida. Thereafter, eggs were stained with $1 \%(\mathrm{w} / \mathrm{v})$ orcein and examined under a phasecontrast microscope (Funahashi and Day, 1993c).

\section{Statistical analysis}

Statistical analyses from four replicate trials for treatment comparisons were carried out by analysis of variance (ANOVA) and Fisher's protected least significant difference test using the StATView (Abacus Concepts, Inc, Berkeley, CA) program. All percentage data were subjected to arc sine transformation before statistical analysis. Correlation coefficients were assessed after Fisher's $\mathrm{R}$ to $\mathrm{Z}$ transformation. The mean concentrations of oestradiol and progesterone in media were expressed as means $\pm \mathrm{SD}$. Probability of $P<0.05$ was considered to be statistically significant.

\section{Results}

Effects of hormonal conditions during the second half of maturation in vitro

There were no differences $(P>0.05)$ among treatment groups in maturation rates 12 and $18 \mathrm{~h}$ after insemination $(90.3 \pm 7.0 \%$ and $94.1 \pm 6.4 \%$, respectively), penetration rates $(80.8 \pm 18.1 \%$ and $84.9 \pm 19.0 \%$, respectively) or polyspermy rates $(60.8 \pm 29.5 \%$ and $74.1 \pm 23.3 \%$, respectively), but groups were different $(P<0.001)$ in rates of male pronuclear formation (Tables $I$ and 2). The highest proportion of male pronuclei was observed in media with no hormonal supplement, although inclusion of hCG or PMSG with hCG did not significantly reduce this proportion (Fig. 1). Male pronuclear formation rates in pig oocytes that were exposed to oestradiol alone or in combination with other hormonal supplements during the second half of the culture period were significantly lower ( $16-26 \%$ at $12 \mathrm{~h}$, and $31-39 \%$ at $18 \mathrm{~h}$ after insemination) than those cultured in media containing hCG or no hormonal supplements (52 and $64 \%$ at $12 \mathrm{~h}$, and 67 and $70 \%$ at $18 \mathrm{~h}$ after insemination, respectively). Supplementation with PMSG in combination with hCG did not decrease the ability of oocytes to form a male pronucleus $(44 \%$ at $12 \mathrm{~h}$ and $58 \%$ at $18 \mathrm{~h}$ after insemination) compared with supplementation with hCG alone or no hormonal supplements (see above), but the pronuclear rate was reduced when PMSG was supplemented alone (34\% at $12 \mathrm{~h}$ and $44 \%$ at $18 \mathrm{~h}$ ). Although there were no correlations $(P>0.05)$ among meiotic maturation, sperm penetration and male pronuclear formation, there was a high correlation $(P<0.0001)$ between male pronuclear formation rates 12 and $18 \mathrm{~h}$ after insemination. 
Table 2. Effects of hormonal supplements between 20 and $40 \mathrm{~h}$ of in vitro maturation on sperm penetration and male pronuclear formation in pigs $18 \mathrm{~h}$ after insemination

\begin{tabular}{|c|c|c|c|c|c|}
\hline \multirow[b]{2}{*}{ Hormonal supplements ${ }^{a}$} & \multicolumn{3}{|c|}{ Number of oocytes } & \multirow{2}{*}{$\begin{array}{c}\text { Number (\%) of } \\
\text { polyspermic oocytes }\end{array}$} & \multirow{2}{*}{$\begin{array}{c}\text { Number }(\%) \text { of } \\
\text { oocytes with male } \\
\text { and female pronuclei }{ }^{\mathrm{c}, \mathrm{d}}\end{array}$} \\
\hline & Examined & Matured (\%) & Penetrated $(\%)^{b}$ & & \\
\hline PMSG + hCG + oestradiol & 72 & $65(90)$ & $57(88)$ & $44(77)$ & $22(38)^{*, \dagger}$ \\
\hline PMSG + hCG & 81 & $77(95)$ & $73(95)$ & $57(78)$ & $42(58)^{* . \ddagger}$ \\
\hline PMSG + oestradiol & 81 & $73(90)$ & $57(78)$ & $39(68)$ & $22(39)^{*}$ \\
\hline hCG + oestradiol & 59 & $57(97)$ & $47(82)$ & $37(79)$ & $16(34)^{* . \dagger}$ \\
\hline PMSG & 74 & $70(95)$ & $61(87)$ & $54(89)$ & $27(44)^{*}$ \\
\hline hCG & 66 & $65(98)$ & $48(74)$ & $39(81)$ & $32(67)^{\ddagger}$ \\
\hline Oestradiol & 78 & $75(96)$ & $55(73)$ & $37(67)$ & $16(31)^{\dagger}$ \\
\hline None & 57 & $54(95)$ & $44(81)$ & $34(77)$ & $31(70)^{\ddagger}$ \\
\hline
\end{tabular}

aPMSG: 10 iu pregnant mares' serum gonadotrophin $\mathrm{ml}^{-1}$; hCG: 10 iu human chorionic gonadotrophin $\mathrm{ml}^{-1}$; oestradiol: $1 \mu \mathrm{g}$ oestradiol $\mathrm{ml}^{-1}$.

'Percentage of oocytes matured.

cPercentage of oocytes penetrated.

${ }^{d}$ Different superscripts within columns denote significant differences $(P<0.05)$.

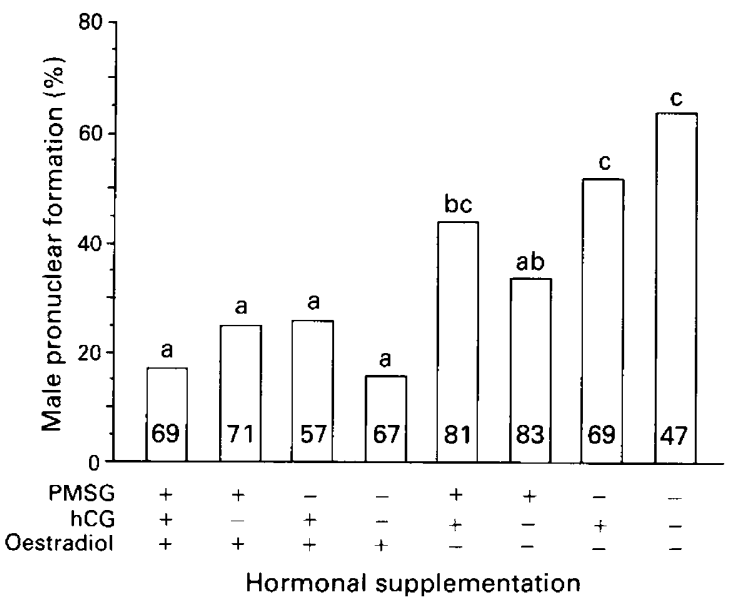

Fig. 1. Effects of hormonal supplements between 20 and $40 \mathrm{~h}$ of maturation in vitro on male pronuclear formation in pigs $12 \mathrm{~h}$ after insemination. Pig oocyte-cumulus complexes were exposed to several combinations of pregnant mares' serum gonadotrophin (PMSG) (10 iu $\mathrm{ml}^{-1}$ ), hCG (10 iu $\mathrm{ml}^{-1}$ ) and oestradiol $\left(1 \mu \mathrm{g} \mathrm{ml}^{-1}\right)$ for a second $20 \mathrm{~h}$ period following culture in a medium supplemented with these hormones for $20 \mathrm{~h}$. The numbers in the bars refer to the numbers of oocytes penetrated in the presence of the hormones indicated (see Table 1). Columns with different letters above the bars denote significant difference $(P<0.05)$.

\section{Effects of hormonal conditions during the first half of maturation in vitro}

There were differences $(P<0.05)$ among treatment groups in the percentage of oocytes with germinal vesicle breakdown, maturation rate, penetration rate and rate of male pronuclear formation, but groups were not different in polyspermy rate $(93.5 \pm 6.8 \%) 12 \mathrm{~h}$ after insemination (Table 3$)$. There were beneficial effects of some hormones upon germinal vesicle breakdown, meiotic maturation, penetration and male pronuclear formation when compared with medium having no hormonal supplement. The germinal vesicle breakdown rates and maturation rates were higher when exposed to PMSG, hCG or PMSG and hCG together $(89-99 \%$ and $71-89 \%$, respectively) than to oestradiol or no hormones $(68-70 \%$ and $45-49 \%$, respectively). Exposure of oocytes to oestradiol alone for the first $20 \mathrm{~h}$ period of culture resulted in a lower penetration rate $(61 \%)$ compared with exposure to PMSG, hCG, or PMSG and hCG together (86-99\%). Supplementation of oocytes with PMSG alone or together with other hormones during the first $20 \mathrm{~h}$ period of culture significantly increased the incidence of male pronuclear formation (63-72\%) compared with supplementation with oestradiol $(33 \%)$ or no hormones $(32 \%)$. There were significant correlations between meiotic maturation rate and penetration rate $(P<0.01)$, between germinal vesicle breakdown rate and male pronuclear formation rate $(P<0.0005)$, between meiotic maturation rate and male pronuclear formation rate $(P<0.0005)$ and between sperm penetration rate and male pronuclear formation rate $(P<0.025)$.

\section{Concentrations of oestradiol and progesterone in culture media during maturation in vitro}

The concentration of oestradiol in maturation medium decreased dramatically from $1309.8 \pm 70.8 \mathrm{ng} \mathrm{ml}^{-1}$ to $216.5 \pm 72.6 \mathrm{ng} \mathrm{ml}^{-1}$ at filtration before culture. The oestradiol concentration was further reduced while under paraffin oil to $128.0 \pm 13.3 \mathrm{ng} \mathrm{ml}^{-1}$ by the end of equilibration and to $42.8 \pm 19.4 \mathrm{ng} \mathrm{ml}^{-1}$ after $20 \mathrm{~h}$ of culture (Fig. 2a), while culture without paraffin oil did not result in a lower oestradiol concentration $\left(234.8 \pm 47.4 \mathrm{ng} \mathrm{ml}^{-1}\right.$ and $225.0 \pm 19.4 \mathrm{ng}$ $\mathrm{ml}^{-1}$, respectively). The concentrations of oestradiol at the end of the second $20 \mathrm{~h}$ period were $39.5 \pm 11.4 \mathrm{ng} \mathrm{ml} \mathrm{m}^{-1}$ and $228.3 \pm 20.6 \mathrm{ng} \mathrm{ml}^{-1}$ in mM199 containing $10 \%$ PFF supplemented with PMSG, hCG and oestradiol in the presence and absence of paraffin oil, respectively, and $0.925 \pm 0.544 \mathrm{ng}$ $\mathrm{ml}^{-1}$ and $6.1 \pm 3.645 \mathrm{ng} \mathrm{ml}^{-1}$ in mM199 containing $10 \%$ PFF under the presence and absence of paraffin oil, respectively (Fig. 2a). 
Table 3. Effects of hormonal supplements between 0 and $20 \mathrm{~h}$ of in vitro maturation on meiotic maturation, sperm penetration and male pronuclear formation in pigs $12 \mathrm{~h}$ after insemination

\begin{tabular}{|c|c|c|c|c|c|c|}
\hline \multirow[b]{2}{*}{ Hormonal supplements ${ }^{\mathrm{a}}$} & \multicolumn{4}{|c|}{ Number of oocytes } & \multirow{2}{*}{$\begin{array}{c}\text { Number }(\%) \text { of } \\
\text { polyspermic oocytes }\end{array}$} & \multirow{2}{*}{$\begin{array}{c}\text { Number (\%) of } \\
\text { oocytes with male } \\
\text { and female pronuclei, }\end{array}$} \\
\hline & Examined & $\operatorname{GVBD}(\%)^{b}$ & Matured $(\%)^{b}$ & Penetrated $(\%)^{\mathrm{b}, \mathrm{c}}$ & & \\
\hline PMSG + hCG + oestradiol & 121 & $118(98)^{*}$ & $107(88)^{*}$ & $92(86)^{* . \dagger}$ & $66(72)$ & $61(66)^{*}$ \\
\hline PMSG + hCG & 103 & $102(99)^{*}$ & $88(85)^{*}$ & $85(97)^{* . \dagger}$ & $60(71)$ & $55(65)^{*}$ \\
\hline PMSG + oestradiol & 103 & $100(97)^{*}$ & $91(88)^{*}$ & $84(92)^{*, \dagger}$ & $60(71)$ & $53(63)^{*}$ \\
\hline hCG + oestradiol & 120 & $110(92)^{*}$ & $85(71)^{*}$ & $77(91)^{* \dagger \dagger}$ & $52(68)$ & $42(55)^{* \dagger}+$ \\
\hline PMSG & 113 & $110(97)^{*}$ & $101(89)^{*}$ & $98(97)^{* . \dagger}$ & $71(72)$ & $71(72)^{*}$ \\
\hline hCG & 120 & $107(89)^{*}$ & $96(80)^{*}$ & $95(99)^{\dagger}$ & $69(73)$ & $52(55)^{* . \dagger}$ \\
\hline Oestradiol & 121 & $85(70)^{\dagger}$ & $54(45)^{\dagger}$ & $33(61)^{\ddagger}$ & $22(67)$ & $11(33)^{\dagger}$ \\
\hline None & 132 & $90(68)^{\dagger}$ & $65(49)^{\dagger}$ & $53(82)^{*}$ & $38(72)$ & $17(32)^{\dagger}$ \\
\hline
\end{tabular}

aPMSG: 10 iu pregnant mares' serum gonadotrophin $\mathrm{ml}^{-1}$; hCG: 10 iu human chorionic gonadotrophin $\mathrm{ml}^{-1}$; oestradiol: $1 \mu \mathrm{g}$ oestradiol ml ${ }^{-1}$.

${ }^{b}$ Different superscripts within columns denote significant differences $(P<0.05)$.

'Percentage of oocytes matured.

dPercentage of oocytes penetrated.

GVBD: germinal vesicle breakdown.

The concentrations of progesterone in maturation media under the presence of paraffin oil were not different throughout equilibration (from $3.6 \pm 0.3 \mathrm{ng} \mathrm{ml}^{-1}$ to $1.0 \pm 0.2 \mathrm{ng} \mathrm{ml}^{-1}$ ) and culture for maturation $\left(2.4 \pm 0.5 \mathrm{ng} \mathrm{ml}^{-1}\right.$ after $20 \mathrm{~h}$ and $5.3 \pm 1.5 \mathrm{ng} \mathrm{ml}^{-1}$ to $6.9 \pm 1.5 \mathrm{ng} \mathrm{ml}^{-1}$ after $40 \mathrm{~h}$ of culture), whereas in the absence of paraffin oil the concentrations increased during culture $\left(3.0 \pm 0.3 \mathrm{ng} \mathrm{ml}^{-1}\right.$ at the start of culture, $16.2 \pm 5.4 \mathrm{ng} \mathrm{ml}^{-1}$ after $20 \mathrm{~h}$, and $46.1 \pm 16.8 \mathrm{ng}$ $\mathrm{ml}^{-1}$ to $52.6 \pm 16.1 \mathrm{ng} \mathrm{ml}^{-1}$ after $40 \mathrm{~h}$ of culture; Fig. $2 \mathrm{~b}$ ).

\section{Discussion}

Meiotic maturation of pig oocytes is induced by culture with media containing PMSG, hCG or PMSG and hCG with or without oestradiol (Yoshida et al., 1989). In our previous study, the exposure of oocyte-cumulus complexes to hormonal supplements (PMSG, hCG and oestradiol) for only $2 \mathrm{~h}$ enhanced germinal vesicle breakdown and maturation of the oocytes, and nearly all of the oocytes showed meiotic maturation by exposure to hormones for $20 \mathrm{~h}$ or longer (Funahashi and Day, 1993c). The data in the present study demonstrate that the presence of PMSG or hCG or both substances in maturation medium during the primary $20 \mathrm{~h}$ period was sufficient for the accomplishment of germinal vesicle breakdown and meiotic maturation. Also, the addition of everted follicles in the presence of $\mathrm{LH}$ alone or together with $\mathrm{FSH}$ (Mattioli et al., 1991), and supplementation of media with PFF and FSH (Naito et al., 1988) enhances male pronuclear formation of the oocytes after fertilization in vitro. We also reported that removing hormonal supplements after $20 \mathrm{~h}$ of culture improves both cumulus expansion and male pronuclear formation (Funahashi and Day, 1993c). Since cytoplasmic maturation was achieved by exposure to PMSG alone or in combination with hCG in the presence or absence of oestradiol from 0 to $20 \mathrm{~h}$ of culture, the presence of PMSG during the
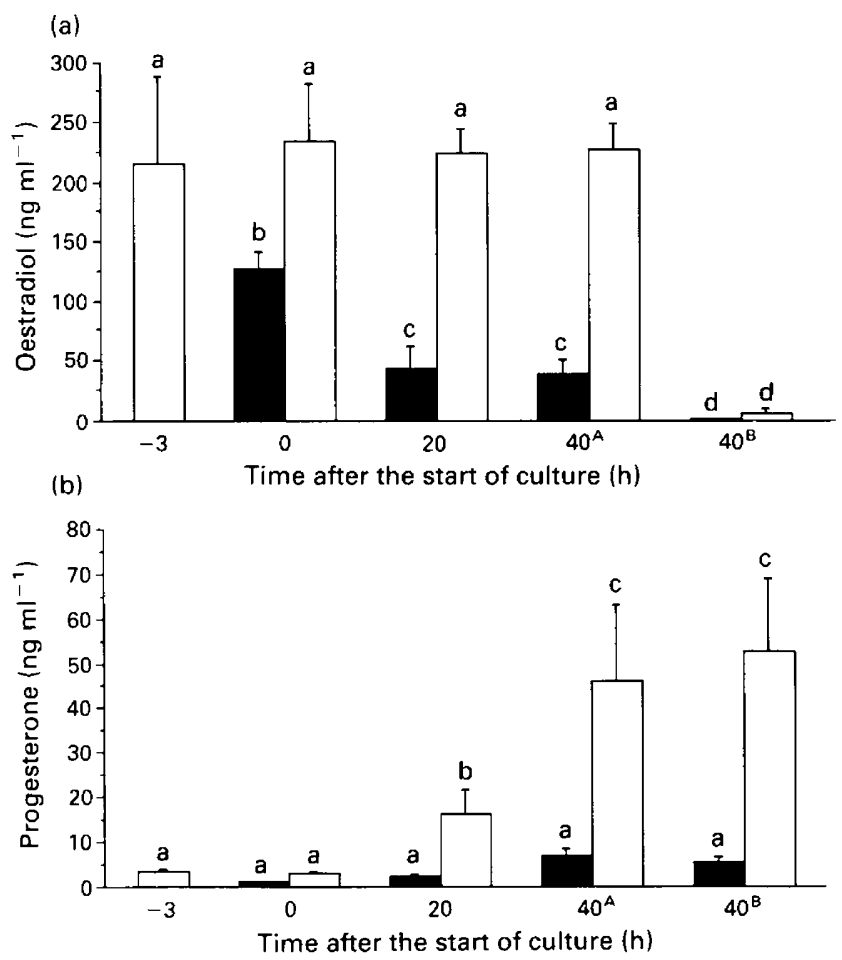

Fig. 2. The change in (a) oestradiol and (b) progesterone concentrations in media during culture of oocyte-cumulus complexes. Pig oocyte-cumulus complexes were cultured in mM199 medium containing $10 \%$ porcine follicular fluid supplemented with $10 \mathrm{iu}$ pregnant mares' serum gonadotrophin (PMSG) $\mathrm{ml}^{-1}, 10 \mathrm{iu}$ hCG $\mathrm{ml}^{-1}$ and $1 \mu \mathrm{g}$ oestradiol ml $\mathrm{ml}^{-\mathrm{I}}$ under the presence $(\square)$ or absence $(\square)$ of $5 \mathrm{ml}$ paraffin oil for $20 \mathrm{~h}$. Thereafter, the complexes were transferred into fresh mM199 containing 10\% porcine follicular fluid supplemented with (column marked $40^{A}$ ) or without (column marked $40^{B}$ ) hormonal supplements for a further $20 \mathrm{~h}$. Columns having different letters above the bars denote significant difference $(P<0.05)$. 
initial $20 \mathrm{~h}$ period appears to promote both meiotic and cytoplasmic maturation.

In the present study, culture of oocyte-cumulus complexes in medium containing PMSG in the presence or absence of oestradiol during a second $20 \mathrm{~h}$ period of culture did not affect meiotic maturation and sperm penetration, but inhibited male pronuclear formation. A high correlation between male pronuclear formation rates 12 and $18 \mathrm{~h}$ after insemination indicates that these differences in male pronuclear formation rates were not due to a delay in the formation of the male pronucleus. The absence of PMSG and oestradiol during a second $20 \mathrm{~h}$ period of culture therefore appears to be beneficial for cytoplasmic maturation. This result is not inconsistent with our previous observation (Funahashi and Day, 1993c). A high incidence of decondensed spermatozoa was obtained after fertilization in vitro when pig oocytes maintained a high degree of intercellular coupling with surrounding cumulus cells until a later stage of maturation (Mattioli et al., 1988). Whereas LH or hCG does not reduce intercellular coupling between cumulus cells and oocytes (Moor and Cran, 1980), LH increases the uptake of $\left[{ }^{3} \mathrm{H}\right]$ uridine in oocyte-cumulus complexes after $26 \mathrm{~h}$ of culture (Mattioli et al., 1991). In contrast, FSH promotes the uncoupling of the cumulus cells from the oocytes and stimulates the cumulus expansion significantly (Moor and Cran, 1980; Eppig, 1982). The existence of PMSG, containing both FSH and LH activity during the later $20 \mathrm{~h}$ period of culture, may reduce the ability of oocytes to form a male pronucleus owing to increased uncoupling between somatic cells and oocytes.

We and other investigators have supplemented maturation medium with a high dose $\left(1 \mu \mathrm{g} \mathrm{ml}^{-1}\right)$ of oestradiol and cultured oocyte-cumulus complexes under paraffin oil (Yoshida et al., 1989, 1990, 1992; Wang et al., 1991; Funahashi and Day, $1993 a, b, c)$. Owing to the high steroid-binding ability of the syringe filter (Racowsky and McGaughey, 1982) and absorbing capability of paraffin oil (Miller and Pursel, 1987), the high concentration of supplemented oestradiol was reduced to concentrations similar to follicular concentrations (Ainsworth et al., 1980) by changing to a medium without hormonal supplements. The concentration of progesterone was also reduced in medium under paraffin oil. Mattioli ef al. (1988) reported that co-culture of oocyte-cumulus complexes with everted follicles in medium supplemented with progesterone resulted in an increase in male pronuclear formation. In the present study, oocyte-cumulus complexes that were cultured under paraffin oil were not exposed to high concentrations of progesterone during maturation but, even so, a high incidence of male pronuclear formation was achieved with suitable gonadotrophin conditions. Exposure to high concentrations of progesterone therefore does not seem to promote cytoplasmic maturation directly.

Recent reports indicate that glutathione is an important factor for male pronuclear formation of pig oocytes (see Niwa, 1993). Further studies will be needed to determine the relationship between hormonal conditions during oocyte maturation and glutathione synthesis in oocyte-cumulus complexes.

In the study reported here, hormonal conditions during maturation did not affect the incidence of polyspermic penetration. Since the number and nature of release of cortical granules in vitro differs from that in vivo (Cran and Cheng, 1986), the culture conditions may be expected to contribute to this abnormal response at fertilization. However, polyspermic penetration of pig oocytes following fertilization in vitro has been inhibited by treatment of spermatozoa with macromolecules secreted by oviductal cells before insemination (Nagai and Moor, 1990) or with porcine follicular fluid (Funahashi and Day, 1993b).

In summary, the data presented here define two different hormonal conditions during maturation in vitro that result in improved cytoplasmic maturation of pig oocytes, namely, presence of PMSG during the first $20 \mathrm{~h}$ of culture and the absence of PMSG and oestradiol during the second $20 \mathrm{~h}$ of culture. It has also been determined that culture of oocytecumulus complexes under paraffin oil results in a marked reduction in the concentrations of steroids in the culture medium.

The authors thank Monfort Pork Inc for their donation of ovaries and B. Nichols for secretarial assistance with the preparation of this manuscript. H. Funahashi is the recipient of a University of Missouri Miller Fund postdoctoral fellowship. This manuscript was funded in part by Farmland Industries and is a contribution from the Missouri Agricultural Experimental Station: Joumal Series Number 11972.

\section{References}

Ainsworth L., Tsang BK, Downey BR, Marcus GJ and Armstrong DT (1980) Interrelationships between follicular fluid steroid levels, gonadotropic stimuli, and oocyte maturation during preovulatory development of porcine follicles Biology of Reproduction 23 621-627

Beckmann LS and Day BN (1993) Effect of media $\mathrm{NaCl}$ concentration and osmolarity on culture of the early stage porcine embryo and viability of embryos cultured in a selected superior medium Theriogenology 39 611-622

Cran DG and Cheng WTK (1986) The cortical reaction in pig oocytes during in vivo and in vitro fertilization Gamete Research 13 241-251

Eppig JJ (1982) The relationship between parthenogenetic embryonic development and cumulus cell-oocyte intercellular coupling during oocyte meiotic maturation Gamete Research 5 229-237

Flowers B, Cantley TC, Martin MJ and Day BN (1989) Effect of elevated ambient temperatures on puberty in gilts Journal of Animal Science 67 779-784

Funahashi $\mathbf{H}$ and Day BN (1993a) Effects of different serum supplements in maturation medium on meiotic and cytoplasmic maturation of pig oocytes Theriogenology 39 965-973

Funahashi H and Day BN (1993b) Effects of follicular fluid at fertilization in vitro on sperm penetration in pig oocytes Journal of Reproduction and Fertility 99 97-103

Funahashi H and Day BN (1993c) Effects of the duration of exposure to supplemental hormones on cytoplasmic maturation of pig oocytes in vitro Joumal of Reproduction and Fertility 98 179-185

Hillensjo T and Channing CP (1980) Gonadotrophin stimulation of steroidogenesis and cellular dispersion in cultured porcine cumuli oophori Gamete Research 3 23,3-240

Hunter RHF, Cook B and Baker TG (1976) Dissociation of response to injected gonadotropin between the Graafian follicle and oocyte in pigs Nature 260 156-158

Kesler DJ, Garverick HA, Youngquist RS, Elmore RG and Bierschwal CJ (1977) Effect of days postpartum and endogenous reproductive hormones on GnRH-induced LH release in daily cows Joumal of Animal Science $\mathbf{4 5}$ 797-803

Lenton EA, King H, Thomas EJ, Smith SK, McLachlan RI, MacNeil S and Cooke ID (1988) The endocrine environment of the human oocyte Journal of Reproduction and Fertility $\mathbf{8 2} 827-841$

McNatty KP, Hunter WM, McNeilly AS and Sawers RS (1975) Changes in the concentration of pituitary and steroid hormones in the follicular fluid of human graafian follicles throughout the menstrual cycle Joumal of Endocrinology 64 555-571

Mattioli M, Galeati G, Bacci ML and Seren E (1988) Follicular factors influence oocyte fertilizability by modulating the intercellular cooperation between cumulus cells and oocyte Gamete Research 21 223-232

Downloaded from Bioscientifica.com at 04/26/2023 12:40:20PM 
Mattioli M, Bacci ML, Galeati G and Seren E (1991) Effects of LH and FSH on the maturation of pig oocytes in vitro Theriogenology 36 95-105

Meinecke B and Meinecke-Tillmenn S (1979) Effects of gonadotropins on oocyte maturation and progesterone production by porcine ovarian follicles cultured in vitro Theriogenology 11 351-365

Miller KF and Pursel VG (1987) Absorption of compounds in medium by the oil covering microdrop cultures Gamete Research 17 57-61

Minato $Y$ and Toyoda $Y$ (1982) Induction of cumulus expansion and maturation division of porcine oocyte-cumulus complexes in vitro Japanese Journal of Zootechnological Science 53 480-487

Moor RM (1974) The ovarian follicle of the sheep: inhibition of oestrogen secretion by luteinizing hormone Journal of Endocrinology 61 455-463

Moor RM and Cran DG (1980) Intercellular coupling in mammalian oocytes. In Development in Mammals pp 3-37 Ed. MH Johnson. Elsevier North-Holland, Amsterdam

Nagai T and Moor RM (1990) Effect of oviduct cells on the incidence of polyspermy in pig eggs fertilized in vitro Molecular Reproduction and Development 26 377-382

Naito K, Fukuda Y and Toyoda Y (1988) Effects of porcine follicular fluid on male pronucleus formation in porcine oocytes matured in vitro Gamete Research $21289-295$

Niwa K (1993) Effectiveness of in vitro maturation and in vitro fertilization techniques in the pig Journal of Reproduction and Fertility Supplement $\mathbf{4 8}$ 49-59
Prochazka R, Nagyova E, Rimkevieova Z, Nagai T, Kikuchi K and Motlik J (1991) Lack of effect of oocytectomy on expansion of the porcine cumulus Journal of Reproduction and Fertility 93 569-576

Racowsky C and McGaughey RW (1982) in the absence of protein, estradiol suppresses meiosis of porcine oocytes in vitro Journal of Experimental Zoology $224103-110$

Redmer DA and Day BN (1981) Ovarian activity and hormonal patterns in gilts fed allyl trenbolone Joumal of Animal Science 53 1088-1094

Wang WH, Niwa K and Okuda K (1991) In-vitro penetration of pig oocytes matured in culture by frozen-thawed ejaculated spermatozoa Journal of Reproduction and Fertility 93 491-496

Yoshida M, Bamba K and Kojima Y (1989) Effects of gonadotropins and estradiol-17 $\beta$ on the timing of nuclear maturation and cumulus mass expansion in pig oocytes cultured in vitro Japanese Joumal of Animal Reproduction 35 86-91

Yoshida M, Ishizaki Y and Kawagishi H (1990) Blastocyst formation by pig embryos resulting from in-vitro fertilization of oocytes matured in vitro Joumal of Reproduction and Fertility 88 1-8

Yoshida M, Ishizaki Y, Kawagishi H, Bamba K and Kojima Y (1992) Effects of pig follicular fluid on maturation of pig oocytes in vitro and on their subsequent fertilizing and developmental capacity in vitro Journal of Reproduction and Fertility 95 481-488 